\title{
ANALISIS SEBARAN PENGGUNAAN AIR DOMESTIK DI KECAMATAN BINJAI KOTA
}

\author{
Hilda Syahrani', Nahor M. Simanungkalit ${ }^{2}$ \\ 'Alumnus S1 Jurusan Pendidikan Geografi Fakultas Ilmu Sosial Universitas Negeri Medan \\ 2Jurusan Pendidikan Geografi Fakultas Ilmu Sosial Universitas Negeri Medan \\ Jl. Willem Iskandar Psr V Medan Estate Medan, 20211 Indonesia \\ Email: hildasyahrani@gmail.com
}

\begin{abstract}
Abstrak:
Tujuan penelitian ini adalah (1) Untuk mengetahui jenis sumber air bersih yang digunakan masyarakat dalam memenuhi kebutuhan air domestik di Kecamatan Binjai Kota, (2) Untuk mengetahui jumlah pemakaian air bersih untuk kebutuhan domestik per bulan per kapita di Kecamatan Binjai Kota. Populasi dalam penelitian ini adalah seluruh kepala keluarga yang ada di Kecamatan Binjai Kota dan sampel dalam penelitian ini diambil dengan menggunakan stratified random sampling yaitu mengambil sampel dengan memperhatikan strata di dalam populasi.Teknik analisis data menggunakan jenis analisis deskriptif yang digunakan adalah analisis deskriptif dalam presentase. Hasil penelitian menunjukkan bahwa (1) Jenis sumber air bersih yang digunakan masyarakat dalam memenuhi kebutuhan air domestik di Kecamatan Binjai Kota adalah PDAM yaitu sebanyak 63 jiwa (63\%) dan Sumur sebanyak 37 jiwa (37\%). (2) Penggunaan air domestik di Kecamatan Binjai Kota tahun 2016 menurut hasil penelitian adalah sebesar 235,2 liter/kapita/hari.
\end{abstract}

Kata kunci : sebaran, air domestic, binjai kota

\section{PENDAHULUAN}

Pada dasarnya mutu hidup manusia adalah terpenuhinya kebutuhan dasar mereka. Dimana kebutuhan dasar antara lain kebutuhan pangan, air bersih, pendidikan, pekerjaan dan rumah. Pertumbuhan penduduk yang terus meningkat secara tidak langsung harus sejalan dengan peranan sumberdaya yang ada. Salah satu sumberdaya yang sangat berperan dalam proses kehidupan manusia adalah sumberdaya air. Air adalah unsur yang tidak dapat dipisahkan dari kehidupan manusia. Bahkan dapat dipastikan tanpa pengembangan sumberdaya air secara konsisten peradaban manusia tidak akan mencapai tingkat yang dinikmati sampai saat ini. Oleh karena itu pengembanganan dan pengelolahan sumberdaya air merupakan dasar peradaban manusia (Sunaryo, dkk, 2005).

Kegunaan air secara universal atau menyeluruh dari setiap aspek kehidupan menjadi semakin berharganya air baik jika dilihat dari segi kuantitas maupun kualitasnya. Semakin tinggi taraf khidupan seseorang, maka kebutuhannya akan air pun semakin meningkat (Unus S, 1996). Air merupakan sumber daya yang sangat diperlukan oleh makhluk hidup baik untuk memenuhi kebutuhannya maupun menopang hidupnya secara alami.

Tidak ada satupun mahkluk yang berada di planet bumi ini yang tidak membutuhkan air. Air adalah materi esensial di dalam kehidupan. Di dalam sel hidup, baik manusia maupun hewan dan tumbuhan akan terkandung sejumlah air, yaitu lebih dari 75\% kandungan sel tumbuhan atau lebih dari $67 \%$ kandungan sel manusia dan hewan terdiri dari air. Di dalam tubuh manusia air diperlukan untuk transportasi zat-zat makanan dalam bentuk larutan dan melarutkan berbagai jenis zat yang diperlukan tubuh. Kihilangan air 15\% dari berat badan dapat mengakibatkan kematian yang disebabkan oleh dehidrasi. 
Air digunakan untuk memenuhi kebutuhan manusia sehari-hari seperti mandi, cuci dan kakus (MCK), untuk pertanian, industri dan kebutuhan air lainnya. Menurut Jacques Diouf Direktur Jendral Organisasi Pangan \& Pertanian Dunia (FAO), saat ini pengguanaan air di dunia naik dua kali lipat lebih dibandingakan dengan seabad silam, namun ketersediaannya justru menurun.

Secara fisik kualitas air dapat dilihat dari bau, rasa, dan kekeruhan kandungan zat padat. Disyaratkan bahwa air minum tidak bewarna, tidak berbau, berasa segar, temperatur maksimal sama dengan temperatur udara, jernih, ( tidak keruh dan kandungan zat padat rendah ). Ketersediaan air dapat mempengaruhi kesejahteraan masyarakat, dan pada suatu daerah ketersediaannya sangat bervariasi dimana ada daerah yang melimpah akan air namun ada yang terbatas.

Pertambahan penduduk membawa konsekuensi terhadap peningkatan kebutuhan akan air baik dari segi kuantitas maupun kualitasnya dan juga menuntut sarana dan prasarana untuk mendukung segala aktivitasnya. Adanya kemajuan yang dicapai manusia dan semakin bertambahnya jumlah penduduk, maka kebutuhan akan air pun semakin meningkat seperti konsumsi air domestik per kapita. Menurut SNI (2002), konsumsi air penduduk pedesaan mencapai 60 L/kapita/hari, konsumsi air penduduk kota kecil mencapai 80 L/.kapita/hari dan konsumsi air penduduk kota besar mencapai 120 L/kapita/hari.

Rata-rata konsumsi air domestik harian per kapita di Indonesia adalah $144 \mathrm{~L}$ atau setara dengan sekitar 8 botol galon air kemasan (Survey Direktorat Pengembangan Air Minum Ditjen Cipta Karya, 2006).

Hal ini menunjukkan bahwa aktifitas manusia sangat memberikan pengaruh terhadap penggunaan air. Semakin maju suatu negara maka semakin tinggi tingkat konsumsi air bersihnya. Jenis penggunaan air dibagi menjadi 2 (dua) bagian yaitu penggunaan air domestik dan non domestik. Dimana kebutuhan domestik meliputi kebutuhan kebutuhan air dalam rumahtangga dan non domestik seperti pariwisata, industri, irigasi, peternakan dan sebagainya. Penggunaan air harus diimbangi oleh ketersediaan air yang ada.

Penggunaan air yang berlebihan dengan ketersediaan air yang terbatas bahkan cendrung semakin berkurang karena menurunnya kondidsi dan daya dukung lingkungan, yang pada akhirnya dapat menyebabkan ketidak seimbang anantara kebutuhan dan ketersediaan air yang mengakibatkan kekeringan dan kerusakan dalam lingkungan.

$$
\text { Menurut S. Alisjahbana, }
$$
mengatakan berdasarkan data terakhir yang didapat pemerintah pada 2011, ketersediaan air bersih di Indonesia baru mencapai $55 \%$ dan target tahun 2015 air minum atau air bersih harusnya coveragennya $68 \%$ sehingga masih kurang $13 \%$ ( Rakor Sumber Daya Air Nasional 2013).

Binjai adalah salah satu kota wilayah provinsi Sumatera Utara, Indonesia. Binjai terletak $22 \mathrm{~km}$ di sebelah barat ibukota provinsi Sumatera Utara, Medan. Letak geografis Binjai $03^{\circ} 03^{\prime} 40^{\prime \prime}$ - $03^{\circ} 40^{\prime} 02^{\prime \prime}$

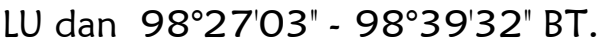

Ada 2 sungai yang membelah Kota Binjai yaitu Sungai Bingai dan Mencirim yang menyuplai kebutuhan sumber air bersih bagi PDAM Tirta Nadi Binjai untuk kemudian disalurkan untuk kebutuhan penduduk kota. Namun di pinggiran kota, masih banyak penduduk yang menggantungkan kebutuhan air mereka kepada air sumur. Ketinggian rata-rata adalah 28 meter di atas permukaan laut. Kota Binjai terbagi atas 5 kecamatan. Lima kecamatan tersebut masing-masing adalah Binjai Kota, Binjai Utara, Binjai Selatan, Binjai Barat, Binjai Timur.

Binjai Kota dengan luas wilayah $4,12 \mathrm{~km}^{2}$ dengan jumlah penduduk pada 
tahun 2015 sebnyak 29.427 orang. Kecamatan Binjai Kota terbagi atas 7 kelurahan yaitu : Binjai, Berngam, Setia, Satria, Tangsi, Kartini, Pekan Binjai. Tingginya kepadatan penduduk di Kecamatan ini dapat mengakibatkan meningkatnya aktivitas manusia seperti perekonomian, kesehatan, dan fasilitas lainnya. Meningkatnya aktivitas manusia otomatis kebutuhan dan penggunaan air akan turut meningkat pula. Tingginya konsumsi dan pemanfaatan sumber air akan mempengaruhi ketersediaan yang ada. Tingkat kebutuhan domestik penduduk tidaklah sama. Hal ini dapat dilatar belakangi oleh kondisi sosial penduduk seperti pendapatan dan pendidikannya. Sumber air yang digunakan masyarakat di Kecamatan Binjai Kota berbeda-beda, sesuai dengan kondidsi sosial ekonomi masyarakat. Dalam kehidupan sehari - hari pemanfaatan air semakin bertambah seiring dengan pertambahan jumlah penduduk. Untuk memenuhi kebutuhan air di Kecamatan Binjai Kota tidaklah cukup oleh PDAM saja, selain itu kondisi sosial ekonomi masyarakat juga melatar belakangi sumber air bersih yang mereka gunakan untuk memenuhi kebutuhan domestik.

\section{METODE PENELITIAN}

Penelitian ini dilakukan di Kecamatan Binjai Kota , Kota Binjai. Kecamatan Binjai Kota mempunyai luas wilayah 4,12 $\mathrm{km}^{2}$ dan terrdiri dari dari 7 kelurahan yaitu Binjai kota, Berngam, Setia, Satria, Tangsi, Kartini, Pekan Binjai. Lokasi penelitian ini dipilih karena merupakan kecamatan yang menjadi pusat pemerintahan kota dengan kepadatan penduduk $7.142 \mathrm{jiwa} / \mathrm{km}^{2}$.

Populasi dalam penelitian ini adalah seluruh kepala keluarga yang ada di Kecamatan Binjai Kota. Berdasarkan Badan Pusat Statistik Kota Binjai yang terdapat dalam Binjai Dalam Angka 2015 jumlah seluruh kepala keluarga di Kecamatan Binjai Kota adalah 7.466 KK.
Sampel adalah sebagian objek populasi yang mewakili karakteristik populasinya. Pengambilan sampel dilakukan dengan menggunakan stratified random sampling yaitu mengambil sampel dengan memperhatikan strata di dalam populasi.

Dalam penelitian ini sampel yang digunakan berdasarkan rumus slovin :

Keterangan :

$$
\mathrm{n}=\frac{N}{1+N e 2}
$$

$\mathrm{n}$ = sampel

$\mathrm{N}=$ populasi (Jumlah Kepala Keluarga)

$\mathrm{e}=$ presentase $(10 \%)$

Maka diperoleh sampel sebesar :

$$
\mathrm{n}=\frac{7466}{1+7466(0,1)^{2}}
$$

$\mathrm{n}=99,67$ maka dibulatkan menjadi 100 responden

Karena kecamatan Binjai Kota memiliki 7 kelurahan maka setiap kelurahan diwakilkan oleh 14,4 responden atau 14 responden .

Jenis data yang dikumpulkan dalam penelitian ini adalah data skunder yang meliputi :

1. Letak, luas, dan batas administrasi

2. Kondisi fisik daerah

3. Jenis air bersih yang digunakan

4. Jumlah air bersih yang digunakan

5. Kondisi sosial ekonomi

6. Peta administrasi Kecamatan Binjai Kota

Untuk lebih jelasnya tentang teknik pengumpulan data yang dipergunakan dilihat dibawah ini :

a. Observasi lapangan

Teknik observasi digunakan peneliti guna mendukung data-data yang dibutuhkan peneliti. Observasi dilakukan terhadap keadaan sosial ekonomi penduduk yang berkaitan dengan jenis air 
bersih yang digunakan dan jumlah air bersih yang digunakan di Kecamatan Binjai Kota.

b. Teknik Komunikasi Langsung

Teknik komunikasi langsung adalah alat yang digunakan lembar wawancara. Sejumlah pertanyaan yang diberikan kapada masyarakat untuk mendapatkan informasi mengenai data yang dibutuhkan dalam penelitian.

\section{c. Teknik studi dokumenter}

Studi dokumenter dilakukan untuk memperoleh data skunder dari instansi terkait yang berhubungan dengan topik penelitian berupa, berbagai keterangan dan dokumentasi yang diperoleh dari kantor - kantor pemerintahan terkait dengan permasalahan yang terdapat di daerah penelitian.

Teknik analisis data yang digunakan adalah Deskriptif Kualitantif yaitu metode yang digunakan untuk menjelaskan datadata yang diperoleh dalam penelitian untuk memperoleh kesimpulan. Jenis analisis deskriptif yang digunakan adalah analisis deskriptif dalam presentase.

\author{
HASIL DAN PEMBAHASAN \\ Jenis Sumber Air Bersih di Kecamatan \\ Binjai Kota \\ Dari hasil penelitian dilapangan
} bahwa dalam memenuhi kebutuhan seharihari sebagian besar masyarakat Kecamatan Binjai Kota memanfaatkan perusahaan air minum (PDAM) sebagai sumber air bersih. Masyararakat Binjai Kota yang paling banyak menggunakan PDAM sebagai sumber air bersih adalah di Kelurahan Berngam dan yang paling sedikit pada Kelurahan Tangsi. Untuk lebih jelasnya dapat dilihat pada Gambar 1. Dari 100 responden sebanyak $63 \%$ masyarakat menggunakan PDAM untuk memenuhi segala kegiatan sehari-hari mulai dari mandi, mencuci, memasak, dan lain-lain. Kondisi sumur dilihat secara fisik dapat dikatakan tidak dapat memenuhi kebutuhan air bersih karena keterbatasan air sumur.

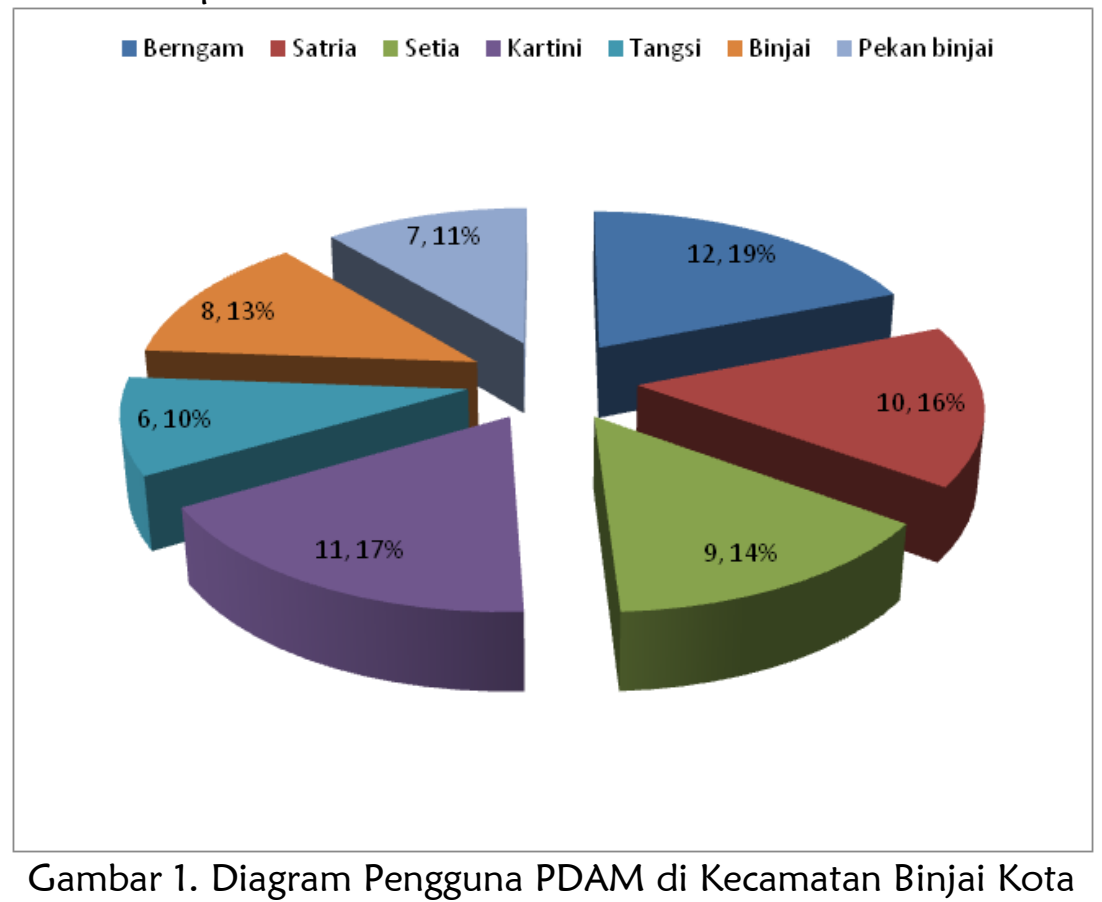

Hal ini merupakan faktor utama banyaknya masyarakat yang menggunakan air PDAM sebagai sumber utama untuk memenuhi kebutuhan air bersih. Terdapat $37 \%$ responden masih menggunakan air sumur. Hal ini karna kondisi sosial dan 
kondisi fisik air sumur sendiri masih ada sebagian yang masih tersedia.

Secara umum masyarakat yang menggunakan PDAM sebagai sumber air bersih mereka merupakan responden yang berpenghasilan diatas Rp. 1.000.000,- dan yang menggunakan sumur merupakan responden yang berpenghasilan dibawah Rp. 1.000.000,- .

\section{Pemanfaatan Sumber Air Bersih Untuk Kebutuhan Domestik di Kecamatan Binjai Kota}

Kebutuhan air bersih sangat bervariasi, menurut Qodriyatun Srinurhayati (2015) ada beberapa faktor yang mempengaruhi penggunaan air bersih yaitu iklim, ciri - ciri penduduk, lingkungan tempat tinggal, iuran atau harga air, dan ukuran kota serta standart kehidupan dan kebiasaan masyarakat itu sendiri. Seperti terlihat pada Tabel 1, Penggunaan air untuk kebutuhan domestik di Kecamatan Binjai Kota didominasi oleh kebutuhan mencuci yaitu 656,78 liter/hari/kk. Berapa banyak frekwensi pemanfaatan air bersih untuk kebutuhan mencuci sangat mempengaruhi banyak atau sedikitnya penggunaan air serta kebiasaan masyarakat yang menggunakan wadah dalam menampung air dapat mengakibatkan pemakaian yang berlebihan. Sebagian besar responden menggunakan ember untuk menampung air karena kondisi fisik air yang kurang baik. Disusul dengan pemanfaatan kegiatan mandi sebanyak 16,01 liter/hari/kk. Pemanfaatan air bersih yang paling sedikit yaitu kebutuhan minum yang hanya 5,05 liter/hari/kk. Sebanyak 67\% masyarakat di Kecamatan Binjai Kota menggunakan air minum isi ulang (AMDK) dalam memenuhi kebutuhannya. Praktis dan murah merupakan faktor utama mengapa banyak masyarakat yang menggunakan air minum isi ulang sebagai sumber air bersih untuk memenuhi kebutuhan minum mereka.

Tabel 1. Penggunaan Air Untuk Kebutuhan Domestik di Kecamatan Binjai Kota Tahun 2016

\begin{tabular}{|c|l|c|}
\hline No. & \multicolumn{1}{|c|}{ Jenis Penggunaan Air } & Volume Penggunaan Air (liter/hari/kk) \\
\hline 1. & Mandi & 16,01 \\
2. & Minum & 5.05 \\
3. & Masak & 14.10 \\
4. & Mencuci & 656,78 \\
5. & Dan lain-lain & 13,64 \\
\hline \multicolumn{2}{|c|}{ jumlah } & 705,61 \\
\hline
\end{tabular}

Sumber : Data Olahan Primer 2016

Kecamatan Binjai Kota memiliki jumlah penduduk sebanyak 29.427 ribu jiwa. Menurut Departeman Pekerjaan Umum bahwa standart kebutuhan air runmah tangga berdasarkan jumlah penduduknya Kecamatan Binjai Kota termasuk dalam katagori tinggi yaitu $>100$ liter/orang/hari.

Sedangkan hasil dilapangan menunjukkan bahwa kebutuhan air bersih untuk Kecamatan Binjai Kota dalam kategori boros. Kerena penggunaan air bersih di Kecamatan Binjai Kota ini hanya digunakan untuk beberapa kebutuhan domestik seperti mandi, mencuci, masak, minum, dan lain - lain. Seharusnya menurup DPU konsumsi air $90-100$ liter/orang/hari sudah untuk seluruh kebutuhan domestik.

Menurut Chandra (2006) ditinjau dari ilmu kesehatan masyarakat, penyediaan sumber air bersih harus dapat memenuhi kebutuhan masyarakat karena persediaan air yang terbatas dapat menimbulkan berbagai jenis penyakit. Volume rata - rata setiap individu per hari berkisaran antara 150 - 200 liter. Namun hasil dilapangan bahwa kebutuhan air 
bersih untuk Kecamatan Binjai Kota adalah 705,61 liter/kk/hari atau 235,2 liter/kapita/hari.

Karakteristik Pemanfaatan Air Bersih dan Kondisi Sosialnya di Kecamatan Binjai Kota Pendidikan sangatlah penting peranannya dalam kehidupan bermasyarakat. Dengan memiliki pendidikan yang cukup maka seseorang akan mengetahui mana yang baik dan mana yang dapat menjadikan seseorang menjadi berguna baik untuk dirinya sendiri maupun untuk orang lain yang membutuhkannya.

Tingkat pendidikan masyarakat Kecamtan Binjai Kota dapat dikatakan baik karena $46 \%$ responden sudah tamat SMA, dan 36\% tingkat sarjana, dan $18 \%$ tamat SMP dan SD. Namun tingginya tingkat pendidikan di Kecamatan Binjai Kota tidak memberikan pengaruh yang signifkan terhadap pemanfaatan air bersih untuk memenuhi kebutuhan domestik di wilayah tersebut.

Tabel 2. Penggunaan Air Bersih dan Tingkat Pendidikan Responden di Kecamatan Binjai Kota Tahun 2016

\begin{tabular}{|c|c|c|c|c|c|c|c|}
\hline \multirow[b]{2}{*}{ No. } & \multirow{2}{*}{$\begin{array}{c}\text { Tingkat } \\
\text { Pendidikan }\end{array}$} & \multicolumn{5}{|c|}{ Jenis Penggunaan Air Bersih (Liter/Hari/KK) } & \multirow{2}{*}{$\begin{array}{l}\text { Jumlah } \\
(\mathrm{l} / \mathrm{h} / \mathrm{kk})\end{array}$} \\
\hline & & Mandi & Minum & Masak & Mencuci & $\begin{array}{l}\text { Dan lain- } \\
\text { lain }\end{array}$ & \\
\hline 1. & $S D$ & 175,8 & 172,2 & 155,2 & 3406,5 & 120,9 & 44336,6 \\
\hline 2. & SMP & 219,75 & 129,125 & 444 & 9509,75 & 422 & 98721,6 \\
\hline 3. & SMA & 396,3261 & 153,0435 & 342,2391 & 17603,33 & 262,87 & 885110,8 \\
\hline 4. & D3 & 352 & 96 & 296 & 6847,5 & 269,5 & 23583,0 \\
\hline 5. & S1 & 468,7059 & 385,2059 & 385,2059 & 26104,12 & 393,8824 & 970799,1 \\
\hline
\end{tabular}

Sumber : Data Primer Olahan 2016

Dari hasil penelitian dilapangan bahwa tingkat pendidikan tidak mempengaruhi berapa besar atau banyak penggunaan air bersih bagi seseorang untuk memenuhi kebutuhan sehari-harinya.

Seharusnya orang yang berpendidikan merupakan seseorang yang telah memiliki suatu proses pembangunan individu dan kepribadian, dan bertanggung jawab dalam meningkatkan pengetahuan sehingga mampu menyesuaikan diri dengan lingkungannya, juga dapat meningkatkan kesempatan berfikir baik secara teoritis maupun praktis untuk menjalani hidup dan kehidupan dalam lingkungan yang selalu berubah.

Dari Tabel 2 dapat dilihat dari tingkat pendidikan S1 membutuhkan air lebih banyak yaitu 970799,1 liter/hari dan tingkat pendidikan D3 membutuhkan air bersih sebanyak 23583,0 liter/hari lebih sedikit dibandingkan dengan tingkat pendidikan SD, SMA, dan SMP. Pendapatan merupakan salah satu faktor yang sangat penting untuk melihat tingkat atau keadaan sosial ekonomi penduduk di suatu daerah. Pendapatan sangat mempengaruhi gaya hidup masyarakat. Semakin tinggi pendapatan seseorang maka semakin meningkat pula kebutuhan hidup seseorang. Secara teori pengertian pendapatan bersifat relatif, tergantung dari mana orang memandang.

Dari hasil data dilapangan bahwa tingkat pendapatan memberikan pengaruh terhadap penggunaan air bersih untuk memenuhi kebutuhan sehari-hari masyarakat Kecamatan Binjai Kota. Dapat dilihat pada tabel bahwa tingkat pendapatan responden antara $\mathrm{Rp}$. 4.000.000 - Rp. 5.000.000,- merupakan tingkat pendapatan yang memiliki kebutuhan air bersih paling tinggi yaitu 10441,36 lite/hari dan pendapatan paling rendah yaitu dibawah Rp. 1.000.000,dengan kebutuhan air bersih 2553,35 liter/hari. Semakin tinggi pendapatan seseorang maka semakin tinggi pula tingkat penggunaan dan kebutuhan airnya. 
Dari tabel silang antara pendidikan, pekerjaan dan pendapatan dapat dikatakan bahwa tingkat pekerjaan responden tidak berpengaruh terhadap jumlah air yang digunakan oleh responden, begitupula dengan tingkat pekerjaan. Berbanding dengan tingkat penghasilan. Tingkat penghasilanlah yang memberikan pengaruh terhadap jumlah penggunaain air terhadap responden. semakin tinggi penghasilan seseorang maka akan semakin tinggi pula tingkat penggunaan air.

Dari hasil data di lapangan dapat diketahui bahwa tingkat penghasilan < Rp.1.000.000, paling banyak menggunakan air adalah responden yang pendidikan SD dibandingkan dengan tingkat pendidikan yang lain. Hal ini dikarenakan responden yang berpendidikan SD paling banyak yang berpenghasilan < Rp. 1.000.000,-Responden dengan tingkat penghasilan Rp. 1.000.000, - Rp. 2.000.000,- yang paling banyak menggunakan air adalah dari responden yang berpendidikan SMP dengan jumlah penggunaan air sebanyak $9.765 \mathrm{l} / \mathrm{bulan} / \mathrm{kk}$. Jika dilihat dari responden yang berpenghasilan $>\mathrm{Rp}$. 2.000.000, - Rp. 3.000.000 yang paling banyak menggunakan air adalah responden yang berpendidikan SMA sebanyak $24.081 \mathrm{l} / \mathrm{bulan} / \mathrm{kk}$. Responden dengan tingkat penghasilan $>$ Rp. 3.000.000 - 4.000.000,- yang paling banyak menggunakan air adalah responden yang berpendidikan $\$ 1$ dengan jumlah penggunaan air sebanyak 43.332 l/bulan/kk. Dan responden dengan penghasilan > Rp. 4.000.000, 5.000.000,- yang paling banyak menggunakan air adalah responden yang dengan tingkat pendidikan SMA dengan jumlah penggunaan air sebanyak 90.7271/bulan/kk. Hal ini dikarenakan responden dengan tingkat pendidikan SMA lebih banyak dari pada responden dengan tingkat pendidikan lain.

Selanjutnya dapat diketahui bahwa responden dengan pekerjaan sebagai wiraswasta paling banyak menggunakan air adalah dari tingkat pendidikan SMA dengan jumlah penggunaan air sebanyak 15.413l/bulan/kk. Hal itu dikarenakan jumlah responden yang bekerja sebagai wiraswasta lebih banyak yang berpendidkan SMA. Responden yang bekerja sebagai PNS/POLRI yang paling banyak menggunakan air adalah dari ingkat pendidikan SMA sebanyak 45.981L/bulan/kk. Responden yang beerja sebagai pegawai swasta yang paling banyak menggunakan air adalah dari pendidikan SMA sebanyak $23.890 \mathrm{l} /$ bulan/kk. Sedangkan responden yang bekerja sebagai karyawan yang paling banyak menggunakan air adalah dari tingkat pendidikan SD yaitu sebanyak $7.953 \mathrm{l} / \mathrm{bulan} / \mathrm{kk}$. responden yang bekerja sebagai pedagang yang paling banyak menggunakan air adalah dari tingkat pendidikan SMA dengan jumlah penggunaan air sebanyak $7.830 \mathrm{l} / \mathrm{bulan} / \mathrm{kk}$. hal ini dikarenakan jumlah responden yang bekerja sebagai pedagang hanya ada yang berpendidikan SMA. Dan responden sebagai pensiunan paling banyak menggunakan air adalah dari tingkat pendidikan S1 sebanyak $7.830 \mathrm{l} / \mathrm{bulan} / \mathrm{kk}$. hal ini dikarenakan responden yang berprofesi sebagai pensiunan hanya berpendidikan $\mathrm{S1}$.

Responden yang bekerja sebagai wiraswasta yang paling banyak menggunakan air adalah responden yang bepenghasilan >Rp.3.000.000,

4.000.000,- dengan jumlah penggunaan air sebanyak 44.304l/bulan/kk. Responden yang bekerja sebagai PNS/POLRI yang paling banyak menggunakan air adalah responden dengan penghasilan $>\mathrm{Rp}$. 4.000.000 - 5.000.000,- dengan jumlah penggunaan air sebanyak 101.058L/bulan/kk. Responden yang bekerja sebagai pegawai swasta paling banyak menggunakan air adalah responden yang berpenghasilan $>\mathrm{Rp}$. 3.000.000, - 4.000.000,- dengan jumlah penggunaan air sebanyak 25822 L/bulan/kk. Sedangkan responden yang bekerja sebagai karyawan yang paling 
banyak menggunakan air adalah dari penghasilan Rp. 1.000.000 - 2.000.000 dengan jumlah penggunaan air sebanyak $7.667 \mathrm{~L} / \mathrm{bulan} / \mathrm{kk}$. Responden yang bekerja sebagai pedagang yang paling banyak menggunakan air adalah responden yang berpenghasilan Rp. 2.000.000, 3.000.000,- sebanyak $7.830 \mathrm{l} / \mathrm{buan} / \mathrm{kk}$. Dan responden yang bekerja sebagai pensiunan dengan penghasilan Rp. 1.000.000, - 2.000.000,- dengan jumlah penggunaan air sebanyak $7.830 \mathrm{l} / \mathrm{bulan} / \mathrm{kk}$.

\section{KESIMPULAN DAN SARAN \\ Kesimpulan}

1. Sumber air yang banyak digunakan masyarakat Kecamatan Binjai Kota adalah PDAM sebanyak 63\% KK dan $37 \%$ masih menggunakan sumur. Namun untuk kebutuhan air minum sebagian besar masyarakat (67\%) memanfaatkan air minum isi ulang (AMDK) karena praktis dan murah dan hanya $33 \%$ yang menggunakan air PDAM dan sumur sebagai sumber air minum mereka.

2. Penggunaan air domestik di Kecamatan Binjai Kota tahun 2016 menurut hasil penelitian adalah sebesar 235,2 liter/kapita/hari yang tergolong boros. Sebaran penggunan air domestik di Kec. Binjai Kota menurut hasil penelitian yang paling tinggi penggunaan airnya adalah di Kelurahan Tangsi yaitu sebanyak 644120 liter/hari/kk dengan jenis sumber air bersih PDAM (10\%) dan sumur (4\%). Kelurahan Tangsi yang paling banyak menggunakan air adalah yang berpenghasilan $>\mathrm{Rp}$. 3.000.000 - Rp. 4.000.000,-. dengan pendidikan S1 (6\%) dan bekerja sebagai PNS/POLRI. Sedangkan yang paling rendah penggunaan air untuk memenuhi kebutuhan air domestik di Kec. Binjai Kota adalah di Kelurahan Pekan Binjai dengan jumlah 133298 liter/hari/kk dengan jenis sumber air bersih PDAM ( 5\%) dan sumur $(10 \%)$ yang didominasi oleh berpenghasilan Rp. 1.000.000 Rp. 2.000.000,- (9\%) dan bekerja sebagai wiraswasta. Hasil penelitian menunjukkan bahwa penggunan air untuk memenuhi kebutuhan air domestik dipengaruhi oleh tingkat pendapatan.

\section{Saran}

1. Diharapkan ada kerja sama antara pemerintah setempat dengan masyarakat dan perusahaan air bersih di wilayah setempat dengan dengan ketersediaan air.

2. Diharapkan kepada warga Kecamatan Binjai Kota untuk menjaga kebersihan kondisi fisik sumber air bersih guna menjaga kelestarian ketersediaan air bersih. Kebersihan lingkungan memberikan pengaruh terhadap air bersih.

3. Diharapkan kepada warga Kecamatan Binjai Kota untuk lebih memperhatikan kuantitas dalam penggunaan air bersih dengan pola dan gaya hidup.

\section{DAFTAR PUSTAKA}

Bernadetta, R., \& Simanungkalit, N. M. (2012). Aliran Air Tanah Pada Akuifer Antara Alur Sungai Tualang dan Sungai Bekala di Kecamatan Pancur Batu Kabupaten Deli Serdang. JURNAL GEOGRAFI, 4(1), 55-66.

Binjai Kota dalam angka 2015

Chandra, budiman. 2007. Pengantar Kesehatan Lingkungan. Jakarta: Penerbit buku kedokteran EGC

Dep. PU Direktorat Jendral Cipta Karya, 2007 "Petunjuk Teknis Pelaksanaan Pengembangan SPAM Sederhana”, Jakarta. 
http://BPS.go.id (diakses pada 3 september 2016)

Parmono, 2011. Penggunaan Air Domestik dan Willingness To Pay Air Bersih PDAM di Kecamatan Temanggung Kabupaten Temanggung: skripsi. Surakarta:Fakultas Keguruan dan Ilmu Pendidikan Universitas Sebelas Maret

Simanungkalit, N. M., \& Lumbantoruan, W. (2016). ANALISIS PERSEBARAN INTRUSI AIR LAUT PADA AIRTANAH FREATIK DI DESA RUGEMUK KECAMATAN PANTAI LABU KABUPATEN DELI SERDANG. JURNAL GEOGRAFI, 8(2), 146-155.

Soekanto, S., 2003. Sosiologi Suatu Pengantar. Jakarta: Rajawali Press.

Soemanto, CD, 1995. Hidrologi Teknik. Jakarta: Penerbit Erlangga
Sutrisno, C Totok, 2000. Teknologi Penyediaan Air Bersih. Jakarta: Rineka Cipta.

Wihertanti, yetty. 2012. Analisis Penggunaan Air Untuk Kebutuhan Domestik di Kecamatan Pacitan Tahun 2012. Skripsi. Surakarta:Fakultas Keguruan dan Ilmu Pendidikan Universitas Sebelas Maret

Winarni, 2011. Analisis Kebutuhan Air Bersih di Kecamatan Sukodono Kabupaten Sragen. Skripsi. Surakarta: fakultas Teknis Universitas Sebelas Maret.

Wulan, Anisa Intan Sari 2005. Kualitas Air Bersih Untuk Pemenuhan Kebutuhan Rumah Tangga di Desa Pesarean Kecamatan Adiwerna Kabupaten Tegal. Skripsi. Semarang: Fakultas Ilmu Sosial Universitas Negeri Semarang 